\title{
The effects of feeding toxic groundnut meal to growing pigs and its interaction with high-copper diets
}

\author{
By R. S. BARBER, R. BRAUDE AND K. G. MITCHELL \\ National Institute for Research in Dairying, Shinfield, Reading, \\ J. D. J. HARDING AND G. LEWIS \\ $M A F F$, Central Veterinary Laboratory, New Haw, Weybridge \\ AND R. M. LOOSMORE \\ $M A F F$, Veterinary Investigation Centre, Coley Park, Reading
}

(Received 55 September 1967-Accepted 13 May 1968)

\begin{abstract}
I. Three experiments using sixty individually fed, enzootic pneumonia-free Large White pigs on experiment from 9-I I weeks of age to 200 lb live weight are described.

2. Information was obtained on the effect of different dietary concentrations of aflatoxin $B_{1}$ on the performance of the pigs, on various biochemical measurements and on the histology of the livers and kidneys.

3. Reduced growth rate and loss of appetite were the main adverse effects observed, their extent being positively related to the dietary level of aflatoxin $\mathrm{B}_{\mathbf{1}}$. No marked clinical signs were seen, mortality was very low and there was little or no effect on the feed conversion efficiency of the animals.

4. No evidence for any adverse interaction between aflatoxin $B_{1}$ and the presence in the diet of a supplement of copper sulphate providing $25^{\circ} \mathrm{ppm} \mathrm{Cu}$ was apparent from either the performance, biochemical or histological results obtained. It was concluded that the few isolated reports of toxicity in growing pigs fed diets containing a supplement of $250 \mathrm{ppm} \mathrm{Cu}$ were unlikely to have been the result of the unsuspected presence of aflatoxin $B_{1}$ in the feedingstuffs used in the diets.

5. Aflatoxin $B_{1}$ tended to increase the serum alkaline phosphatase level, the concentration of $\mathrm{Cu}$ in the kidneys, and liver weight and to reduce the liver vitamin A concentration. No other consistent differences in the measurements made were observed.

6. The extent of the total pathological abnormality observed in the livers and kidneys was closely related to the level of aflatoxin $B_{1}$ in the diet.
\end{abstract}

The first field outbreaks of apparent groundnut poisoning in pigs were described by Loosmore \& Harding (1961), and were subsequently proved experimentally to have been caused by the Brazilian groundnut meal present in the diets given (Harding, Done, Lewis \& Allcroft, 1963 ). It is now known that the toxic factor responsible is a complex toxin known as aflatoxin, produced by certains strains of the fungus, Aspergillus flavus, and present as a contaminant of groundnut meal and other feedingstuffs: aflatoxin $B_{1}$ is the component mainly found and groundnut toxicity is conveniently expressed in terms of ppm of this component (Commercial Research Group, 1964). A general review on aflatoxin poisoning has recently been published by Lysø (1966). Loosmore \& Harding (1961) have commented on the many similarities in the gross and microscopic lesions seen in aflatoxin poisoning and in experimental copper poisoning, as described by Allen \& Harding (1962), which can be confused and lead to incorrect diagnosis unless the recognized differences in the pathology of the two 
toxicity conditions, also discussed by Loosmore \& Harding (1961), are taken into consideration. Among the similarities in lesions of the two toxicity syndromes are the yellow/orange colour of the liver and the disorganization of the normal cord structure and enlarged parenchymal nuclei revealed by histological examination of this organ; in the particular outbreaks described by these workers, however, it was shown that a 'concurrent' $\mathrm{Cu}$ toxicity was not involved. Hornby, Miller \& Dabell (1962) also comment on the similarities between the two toxicity syndromes and described field cases of aflatoxin poisoning which were initially wrongly diagnosed as $\mathrm{Cu}$ toxicity.

A very large number of experiments, involving many thousands of pigs, have now been published confirming the growth-promoting effect of the addition to the diet of $0.1 \%$ copper sulphate (supplying $25 \circ \mathrm{ppm} \mathrm{Cu}$ ) first reported by Barber, Braude, Mitchell \& Cassidy (1955), and recently reviewed by Braude (1965). However, a few isolated cases of toxicity causing deaths in pigs receiving diets supplemented with 250 ppm $\mathrm{Cu}$ or less have been reported (Gordon \& Luke, 1957; O'Hara, Newman \& Jackson, I960; Buntain, 196ı; Bass, McCall, Wallace, Combs, Palmer \& Carpenter, 1956; Wallace, McCall, Bass \& Combs, 1960; Ritchie, Luecke, Baltzer, Miller, Ullrey \& Hoefer, 1963; Hanrahan \& O'Grady, 1966). In the first three of these reports, the evidence for directly associating the symptoms described with dietary $\mathrm{Cu}$ appears to be open to considerable doubt for the reasons discussed at length by Braude (1965). In the remaining cases it appeared to us at the time that, bearing in mind the similarities between the gross lesions of aflatoxin $\mathrm{B}_{1}$ and of $\mathrm{Cu}$ poisoning (as commonly produced when amounts of $\mathrm{Cu}$ much in excess of $25^{\circ} \mathrm{ppm}$ are fed), a possible explanation for the reported observations was that aflatoxin-containing feeding-stuffs had been used unknowingly in the experiments, and that under such conditions the addition of $25^{\circ} \mathrm{ppm} \mathrm{Cu}$ to the diets could have resulted in the production of the toxic symptoms described by the authors. Groundnut meal was not used in any of these experiments, but this does not rule out the possibility of the presence of aflatoxin, as it is known that it can be present in other feeding-stuffs such as maize (Carnaghan \& Allcroft, 1962; Van der Merwe, Fourie \& Scott, 1963), and cottonseed cake (Loosmore, Allcroft, Tutton \& Carnaghan, 1964). The experiments reported here were carried out first to obtain further information on the effects under controlled conditions of different levels of aflatoxin $B_{1}$ in the diet of growing pigs and secondly to determine whether there was any experimental basis for the suggested interaction between aflatoxin and copper.

\section{EXPERIMENTAL}

Three experiments were carried out. In each experiment, litter-mate groups of four Large White pigs, 9-I I weeks old, from the Shinfield enzootic pneumonia-free herd, balanced as far as possible for initial weight and sex, were used and treatments were allocated at random to each group. The number of pigs per treatment in Expts I, 2 and 3 were 3,4 and 8, respectively. All pigs were individually fed twice daily, $3 \mathrm{lb}$ water per $\mathrm{lb}$ feed being added just before feeding. The pigs on each treatment were kept separately. The amount of feed given was adjusted once weekly, following the 
weekly weighing of all pigs, and was according to a scale based on live weight as described by Braude \& Mitchell (195I). The maximum daily allowance of feed/pig was $6.5 \mathrm{lb}$ in Expts $\mathrm{I}$ and 2, and $6 \mathrm{lb}$ in Expt 3. A visual estimate of any feed refused was made daily for each pig; in Expts $I$ and 2 the daily allocation of feed was arbitrarily reduced very slightly if the refusals were substantial, but in Expt 3 the daily allocation of feed based on live weight was continued, no matter how much the pigs refused. Rectal temperatures were taken periodically when pigs were refusing feed.

The pigs were sent to slaughter to the local bacon factory when they exceeded $200 \mathrm{lb}$ live weight at the weekly weighing.

The groundnut meals used in the three experiments were kindly supplied, from single bulk supplies, by the Unilever Research Laboratory, Colworth House, Sharnbrook, Bedford. The non-toxic groundnut meal (NTGM) contained $0.05 \mathrm{ppm}$ or less, and the toxic groundnut meal (TGM) $6 \cdot 0-7 \cdot 5 \mathrm{ppm}$ aflatoxin $\mathrm{B}_{1}$ as determined by the method of de Iongh, van Pelt, Ord \& Barrett (I964). In each experiment there were four treatments: the diets contained 7.5 or $15 \%$ each of either NTGM or TGM and were calculated to contain approximately $10 \mathrm{ppm} \mathrm{Cu}$; they were fed either with or without a supplement of $0.1 \% \mathrm{CuSO}_{4} \cdot{ }_{5} \mathrm{H}_{2} \mathrm{O}$, supplying $250 \mathrm{ppm} \mathrm{Cu}$. The composition of the various experimental diets, when they were fed, and the calculated concentrations of aflatoxin $B_{1}$ are shown in Table $I$; diets contained similar amounts of calcium, phosphorus and $\mathrm{NaCl}$ and were supplemented with vitamins $\mathrm{A}$ and $\mathrm{D}_{3}$.

\section{Biochemical investigations}

Blood. Blood haemoglobin was determined by the method described by Barber, Braude \& Mitchell (I955) in all pigs in Expts I and 2 at weekly or twice-weekly intervals throughout the experimental period. In Expt 3 , the haemoglobin determinations were made at the start of the experiment after 7-II weeks, and shortly before the pigs were slaughtered.

From each pig in Expt 2, a $30 \mathrm{ml}$ blood sample was taken by vena cava puncture after being on experiment for approximately 14 weeks. A similar sample of blood was taken from these pigs and from those in Expts $I$ and 3 at slaughter at bacon weight. The following serum determinations were made: alkaline phosphatase $(E C: 3$. I $\cdot 3$. I, orthophosphoric monoester phosphohydrolase), total protein, albumin and albumin: globulin ratio (all samples); G.o.r. (glutamic-oxaloacetic transaminase, EC: 2.6. I . r, L-aspartate:2-oxoglutarate aminotransferase) and G.P.T. (glutamic pyruvic transaminase, $E C:$ 2.6.1.2, L-alanine:2-oxoglutarate aminotransferase) (all samples except from pigs in Expt 3). Serum samples were examined for alkaline phosphatase by the method of King \& Wootton (1956) and for G.O.T. by a modification of the method of Umbreit, Kingsley, Schaffert \& Siplet (1957). G.P.T. was measured by a modification of the method of Wroblewski \& Caband (1957). Serum proteins (total and albumin) were determined by the biuret method described by King \& Wootton (1956); in each sample globulins were calculated by subtracting the albumin value from that for total serum protein.

Blood samples were also taken from six litter-mate pigs in Expt 3 when they had been on experiment for 7 weeks. Two pigs were bled in each of treatments I (NTGM), 


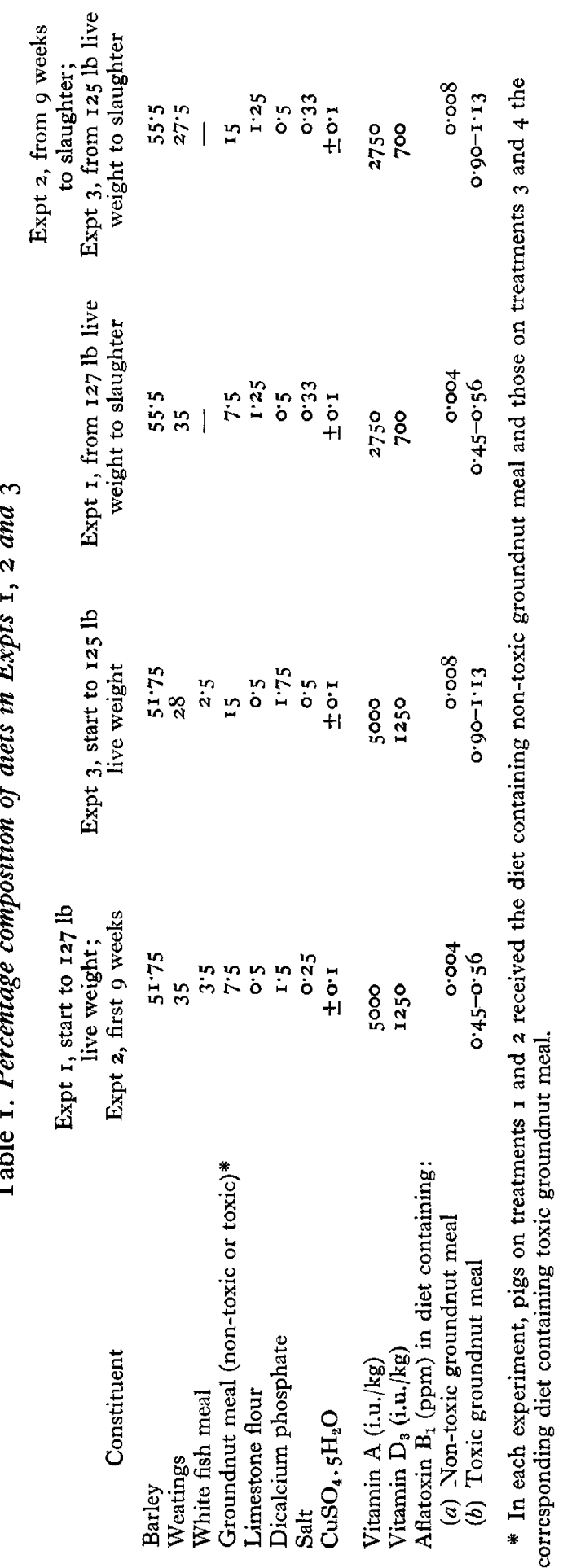


3 (TGM) and 4 ('TGM plus $\mathrm{Cu}$ ) and at the time of sampling one member of each pair in each treatment group was regularly consuming all its daily ration while its pen-mate was refusing a large proportion of feed every day. Standard haematological techniques and analytical procedures were employed to ascertain whether there were any significant haematological differences both within and between the three treatments.

Liver and kidneys. At slaughter, a sample of liver adjacent to the bile duct and a sample of the left kidney (a cross-section from the middle) were taken from all pigs in the three experiments; in Expt 3 the total liver and kidney weights were determined before sampling. The $\mathrm{Cu}$ concentration in each sample was determined by a method based on those described by Eden \& Green (1940) and Clare, Cunningham \& Perrin (r945). Vitamin A levels in the liver were determined by a combination of the methods of Thompson, Ganguly \& Kon (1949) and Carr \& Price (1926). Unfortunately, the liver samples from the pigs in Expt 3 intended for the vitamin A and Cu determinations were lost and hence values for vitamin $A$ are available for pigs from Expts I and 2 only; however, the formalin-fixed samples, collected for histological examination, were available to use for the liver and kidney $\mathrm{Cu}$ determinations in Expt 3 .

One piece of liver and one piece of kidney from each pig were examined histologically without the pathologist knowing from which treatment group they came. The tissues, fixed in $10 \%$ buffered formalin ( $\mathrm{pH}^{\circ} 7^{\circ}$ ), were sectioned at $5-7 \mu \mathrm{m}$ and stained with Ehrlich's haematoxylin and eosin, by a picric acid modification of Masson's trichrome for collagen and by Okamoto \& Utamura's (1937) rubeanic acid method for $\mathrm{Cu}$.

\section{Biometrical methods}

Standard analyses of variance were carried out on each of the variables determined in each experiment, except liver and kidney $\mathrm{Cu}$ concentrations as indicated below, and differences between treatment means were examined by the multiple range test (Duncan, 1955). As there were variance differences between treatments in liver and kidney $\mathrm{Cu}$ concentrations, logarithmic transformations were used in the analyses of these variables, and the $95 \%$ confidence limits of the derived means were determined.

\section{RESULTS}

Out of the total of sixty pigs used in the three experiments only two died, both being in Expt 3 ; one of these was on treatment 3 ( $15 \%$ TGM) and one on treatment 4 ( $15 \%$ TGM plus $0.1 \%$ copper sulphate). The former died when it weighed I $12 \mathrm{lb}$ after being on experiment $2 \mathrm{I}$ weeks and the latter when it weighed IOI $\mathrm{lb}$ after I 6 weeks on experiment. Apart from the lesions found in the liver and kidney from these two pigs, which are discussed later, post-mortem examimation revealed no abnormalities in the pig on treatment 3 ; the pig on treatment 4 was pale in colour and there were pneumonic lesions in both lungs. The alimentary tract was normal except for blood staining of the contents of the large intestine.

No obvious abnormalities were observed in any of the pigs either during the course of the three experiments, apart from substantial refusals of feed by the pigs receiving 


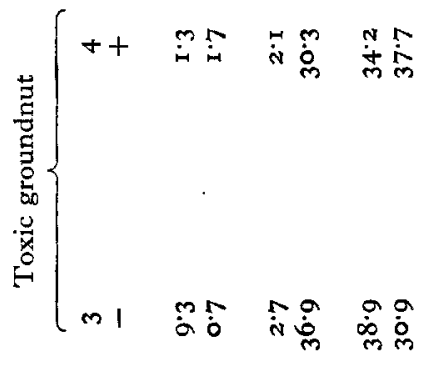

ह

है

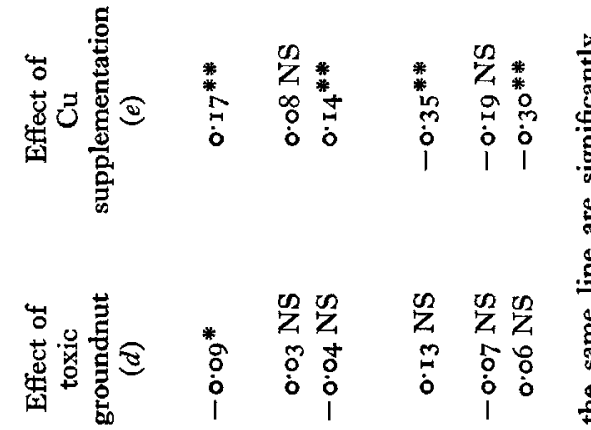

(2)

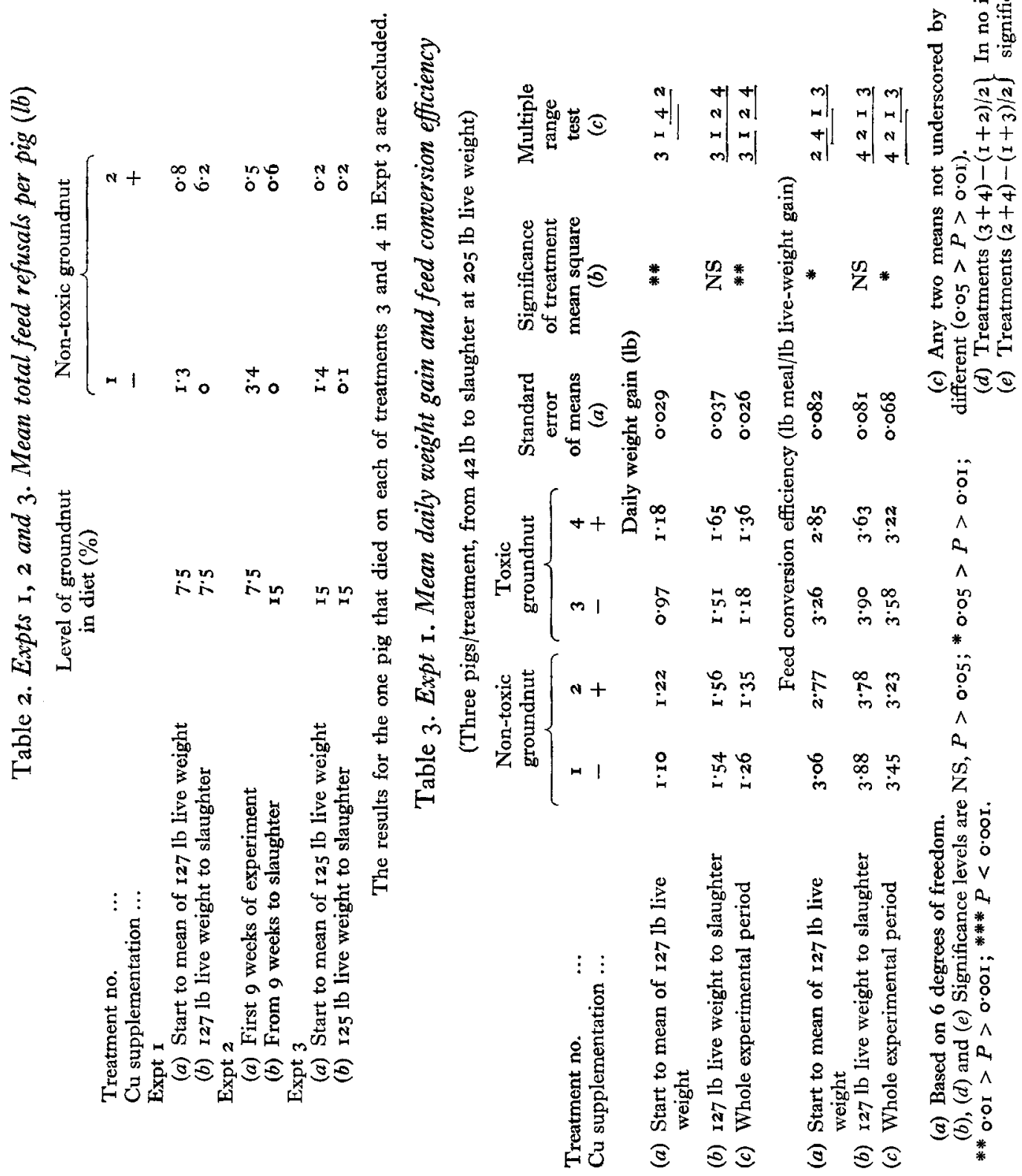




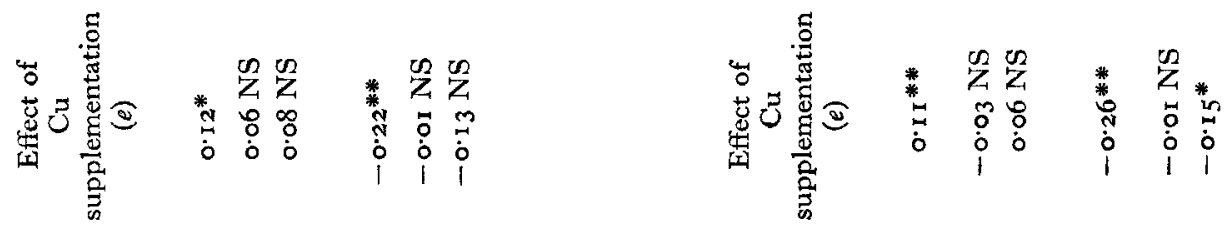

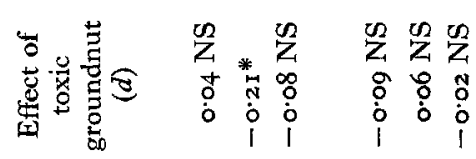

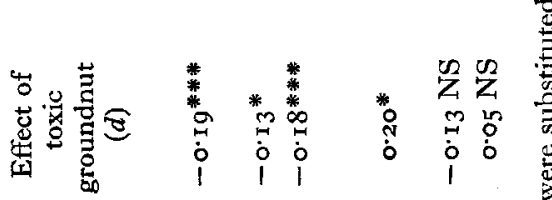

ड़े

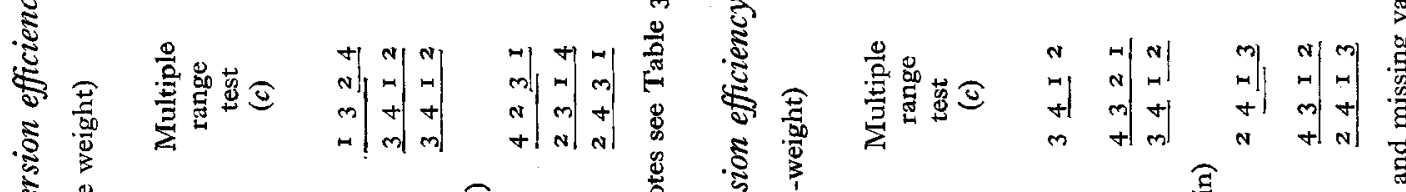

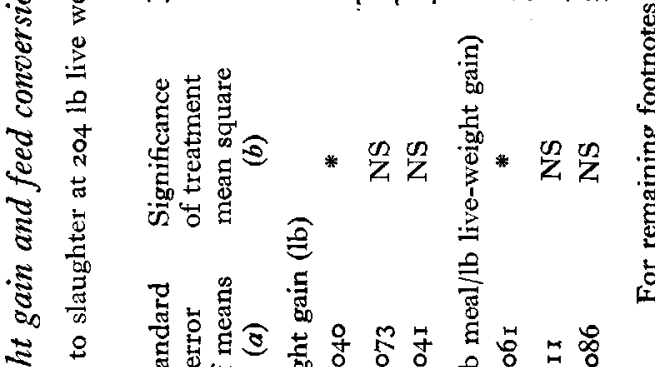

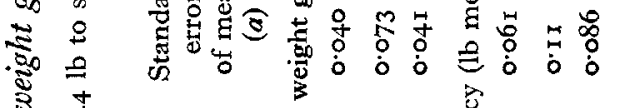

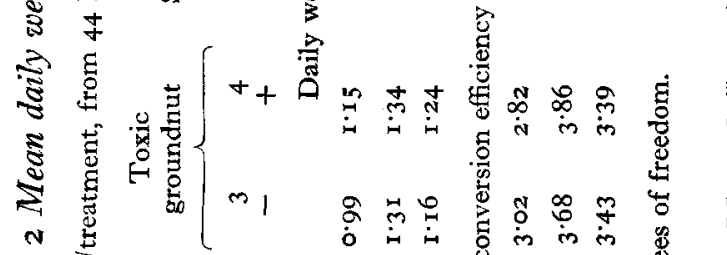

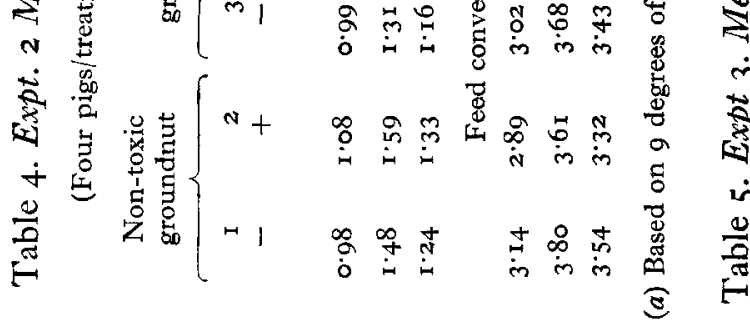
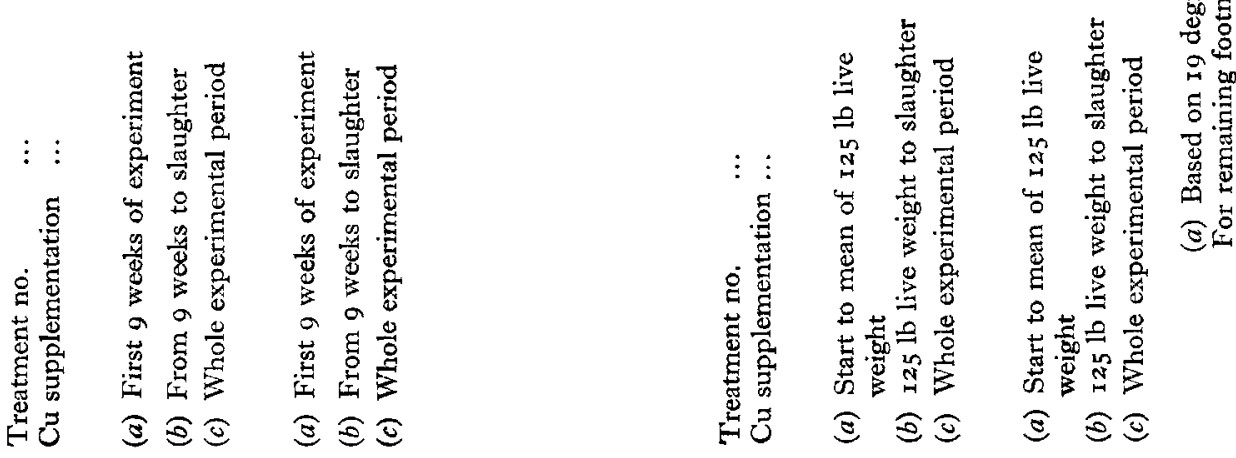
the $15 \%$ TGM diets (Table 2) or in any of the fifty-eight carcasses at slaughter. The rectal temperatures that were taken periodically in pigs persistently refusing feed were, in the majority, well within the normal range.

\section{Daily weight gain and feed conversion efficiency}

Expt r (Table 3). The inclusion of $7.5 \%$ TGM in the diet for the whole experimental period resulted in a reduction in daily weight gain in the period up to $127 \mathrm{lb}$ live weight, particularly when no $\mathrm{Cu}$ supplement was given, but from then until slaughter and taken over the whole experimental period, there were no significant differences in daily weight gain between pigs given the NTGM and TGM diets.

Differences in feed conversion efficiency due to type of groundnut meal were not significant at any stage of the experiment. Feed was refused by two of the three pigs on treatment 3 up to $127 \mathrm{lb}$ live weight and averaged approximately $4.5 \%$ of the feed offered during this period to these two pigs, whereas all the other groups refused very little feed (Table 2).

The addition of $\mathrm{Cu}$ to the NTGM and TGM diets resulted in significant over-all improvements both in daily weight gain and in feed conversion efficiency. These responses to $\mathrm{Cu}$ tended to be larger on the TGM than on the NTGM diets.

Expt 2 (Table 4). During the first 9 weeks of the experiment (from a live weight of approximately $44 \mathrm{lb}$ to $\mathrm{I} 1 \mathrm{O} \mathrm{lb}$ ), the inclusion of $7.5 \%$ TGM had no significant effect on daily weight gain, in contrast to Expt I. However, from 9 weeks to slaughter when I5\% TGM was included, the daily weight gain was significantly reduced irrespective of $\mathrm{Cu}$ supplementation.

Differences in feed conversion efficiency due to type of groundnut meal were again not significant either during the first 9 weeks of the experiment or thereafter to slaughter. Whereas in the first 9 weeks of the experiment, feed refusals were small for all groups, thereafter substantial refusals by seven of the eight pigs in the two groups receiving the TGM diets on treatments 3 and 4 were recorded (Table 2); these averaged in total approximately $10 \%$ of the feed offered to the seven pigs during this period.

The addition of $\mathrm{Cu}$ to the NTGM and TGM diets again improved daily weight gain and feed conversion efficiency although the magnitudes of the responses were lower than occurred in Expt 1 and were significant only during the first 9 weeks of the experiment.

Expt 3 (Table 5). The inclusion of $15 \%$ TGM in the diet for the whole experimental period resulted in significant reductions in daily weight gain at all stages of the growing period, and these effects were independent of the inclusion of the $\mathrm{Cu}$ supplement in the diets. The pigs given TGM had a poorer feed conversion efficiency during the period up to $125 \mathrm{lb}$ live weight than those given NTGM, but during the final period to slaughter weight and taken over the whole experimental period, there were, as in Expts $I$ and 2, no significant differences in feed conversion efficiency due to type of groundnut meal.

Feed refusals by twelve of the fourteen surviving pigs (two pigs died-see Table 5) that received the TGM diets on treatments 3 and 4 were high throughout, 
Vo1. 22

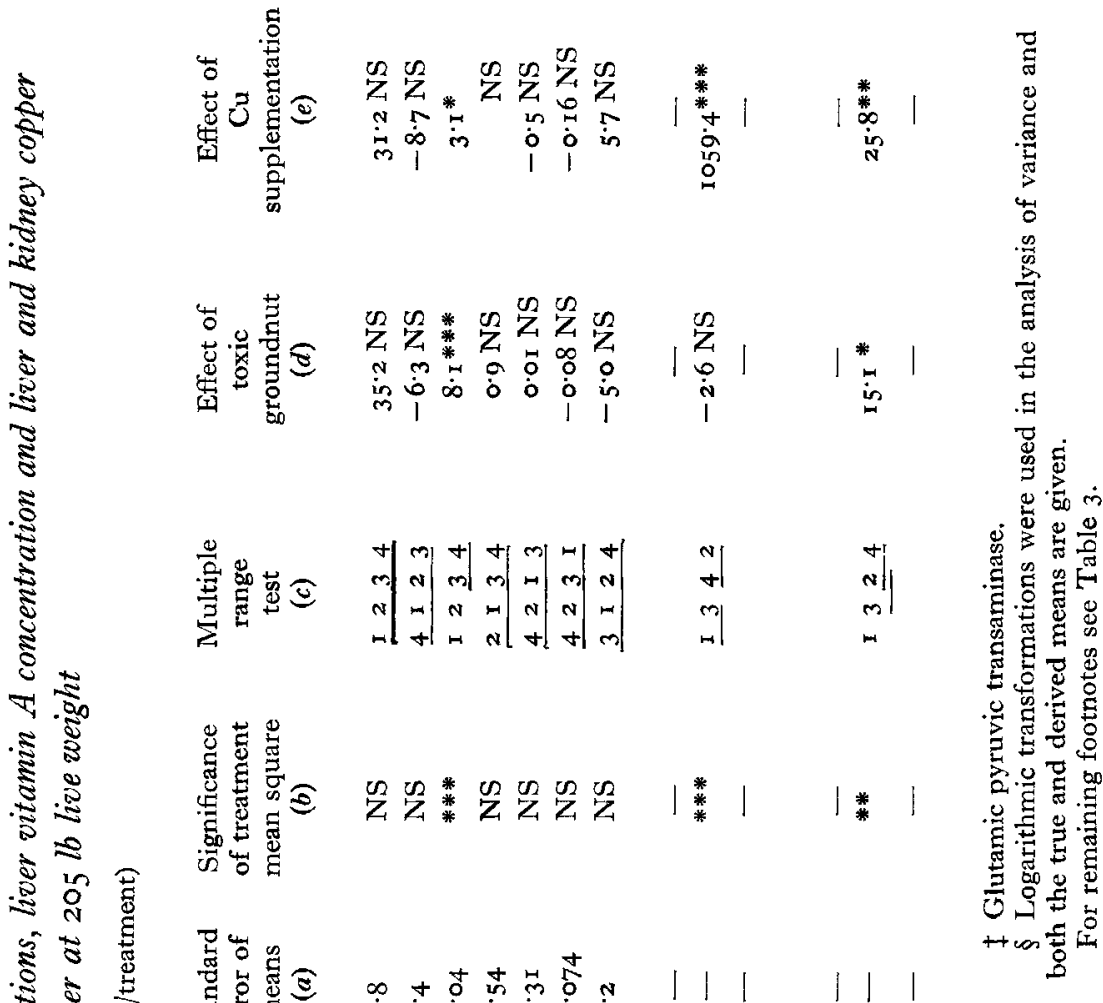



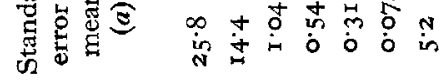

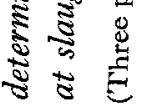

离密

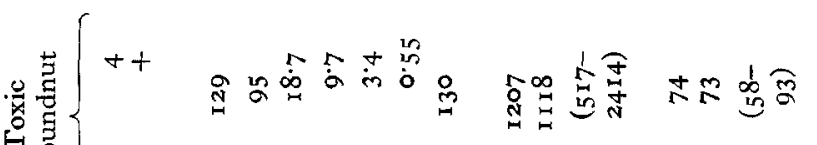

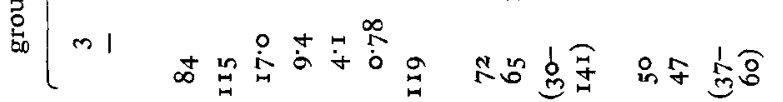

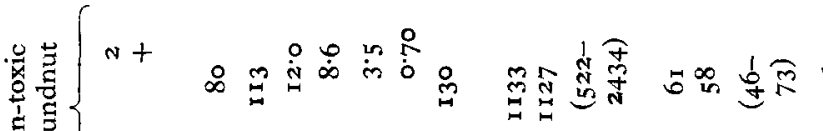

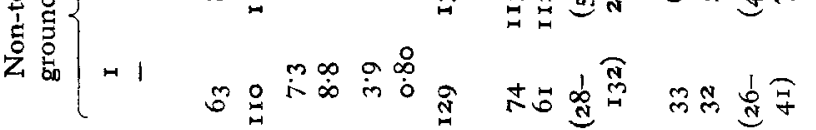

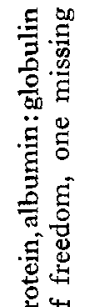
密$$
\text { (1) }
$$
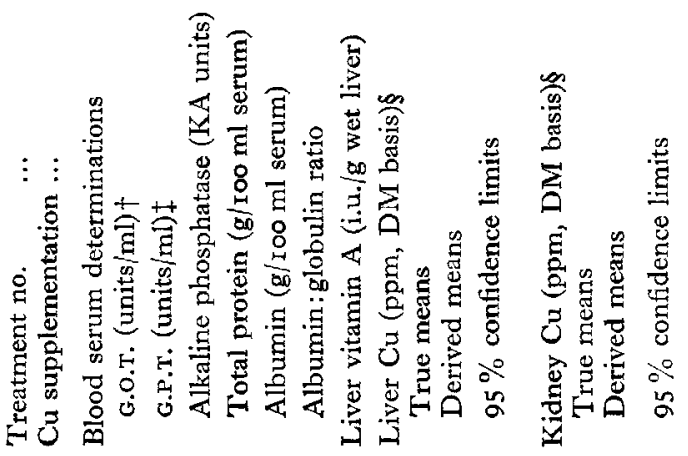

密

政.

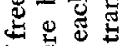

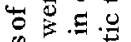

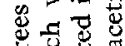

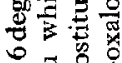

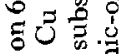

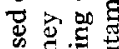

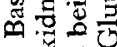

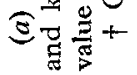




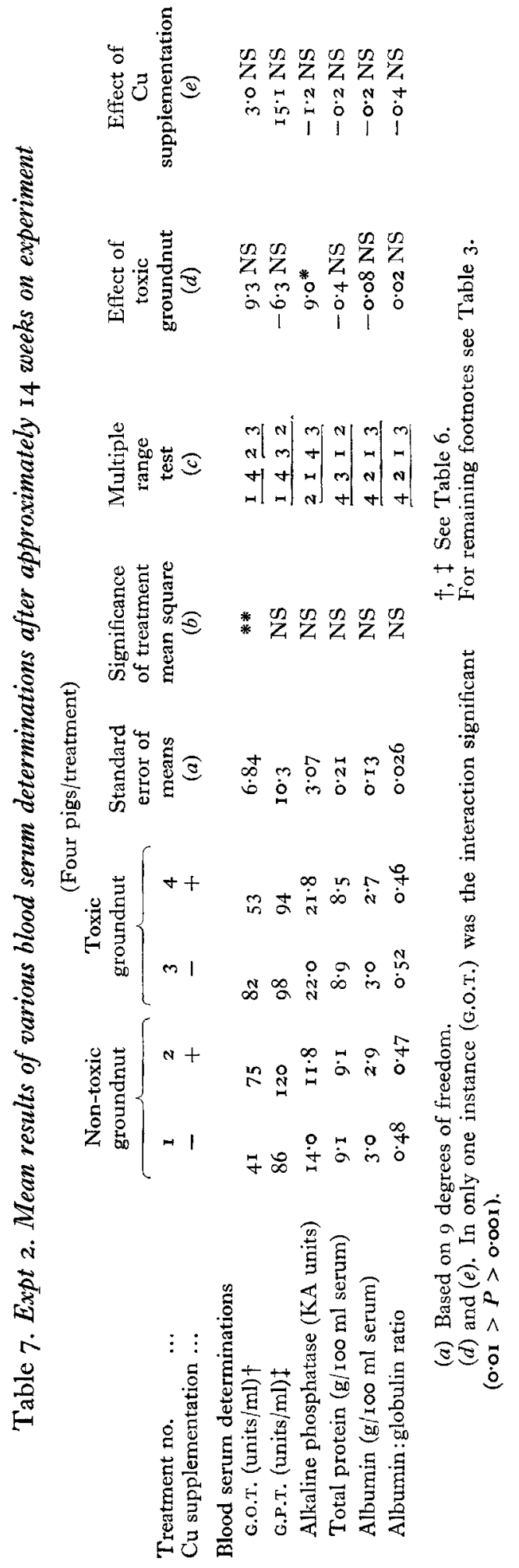




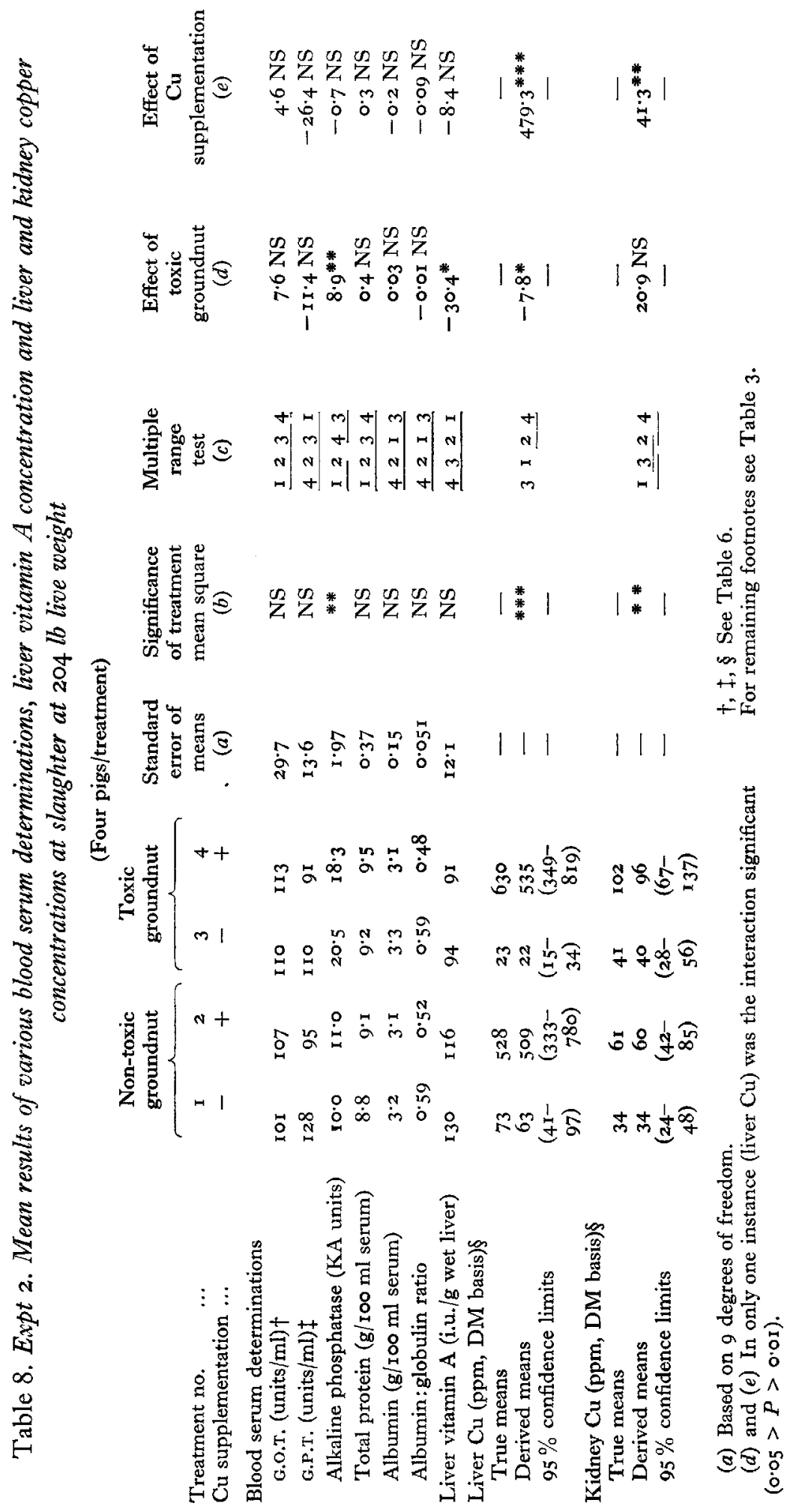




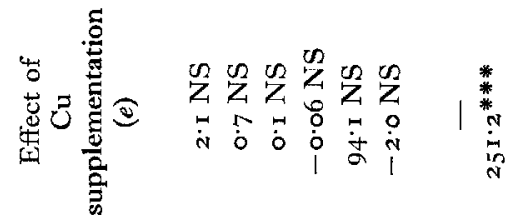

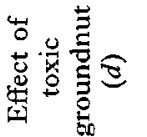

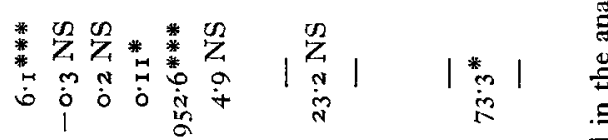

|

递

ฐี้

赵

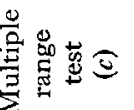

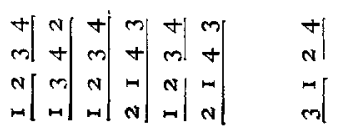

?

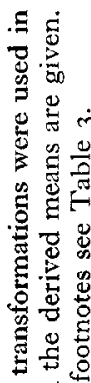

ริ

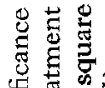

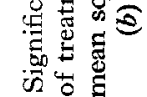

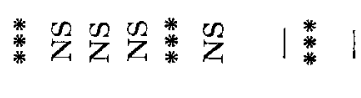

$\stackrel{3}{2} \approx$

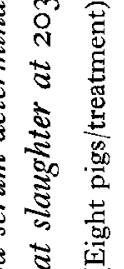

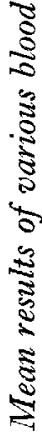

话岁语

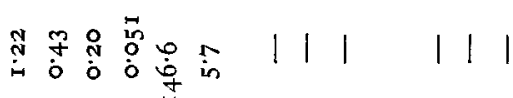

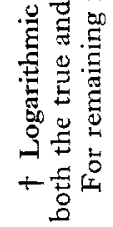

है

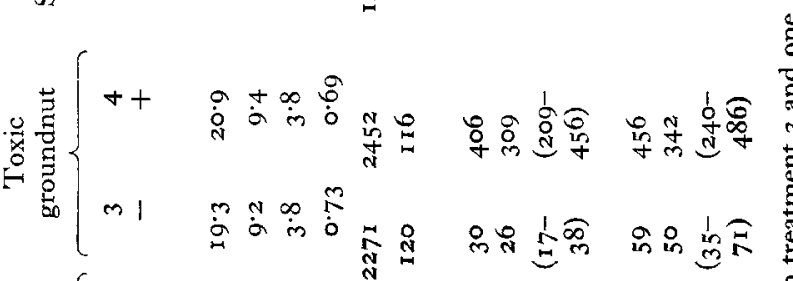

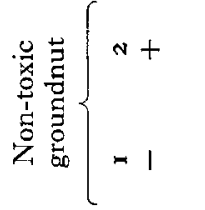

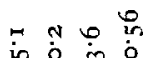

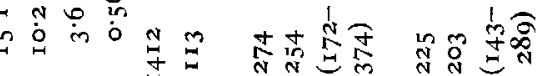

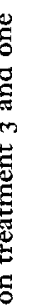

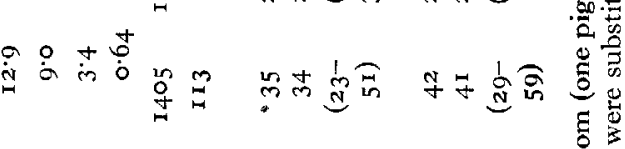

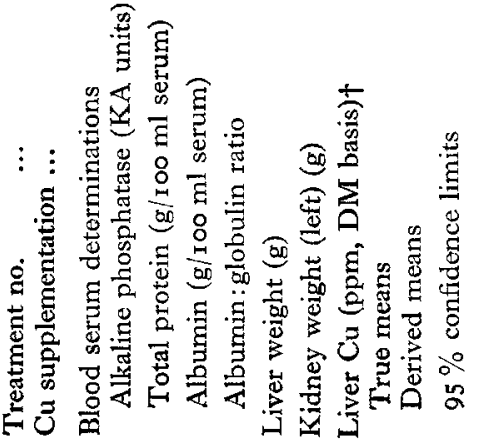

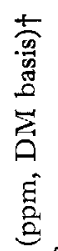

递莺

$\frac{0}{\frac{0}{0}}$

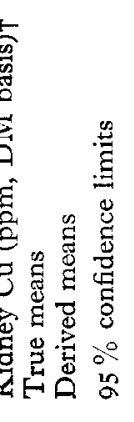


averaging nearly $13 \%$ of the total feed offered during the experiment, and were similar to the refusals in Expt 2 during the time that $15 \%$ TGM was fed (Table 2).

As in Expts I and 2, Cu supplementation significantly improved daily weight gain and feed conversion efficiency during the period up to $25 \mathrm{lb}$ live weight; the magnitudes of the responses were similar in this experiment on both the NTGM and TGM diets. As in Expt 2, there was no significant effect of $\mathrm{Cu}$ on daily weight gain taken over the whole experimental period; there was, however, a significant improvement in feed conversion efficiency over-all although it was smaller in magnitude than that observed in Expt $\mathbf{I}$.

\section{Blood serum investigations}

In each experiment alkaline phosphatase was significantly affected by type of groundnut meal; the presence of TGM in the diet resulted in a significant rise in the serum level of alkaline phosphatase which was independent of $\mathrm{Cu}$ supplementation. With one exception (Expt 3), none of the other variables measured were significantly affected by TGM; in Expt 3 TGM in the diets had the over-all effect of significantly increasing the albumin:globulin ratio although the mean differences were relatively small.

In Expt I (Table 6) addition of $\mathrm{Cu}$ to the diets caused the serum alkaline phosphatase level to increase, the difference being statistically significant on the NTGM diets only. In Expt 2, both after I4 weeks (Table 7) and at slaughter (Table 8), and in Expt 3 (Table 9) $\mathrm{Cu}$ supplementation had no significant independent effect on any of the variables measured. In the samples taken after 14 weeks in Expt 2 there was a significant interaction between type of groundnut meal and $\mathrm{Cu}$ supplementation in relation to the concentration of G.O.T. in serum. Thus, TGM significantly affected G.O.T., the level being increased in the absence of $\mathrm{Cu}$ supplementation and reduced in its presence. Addition of $\mathrm{Cu}$ to the NTGM diets significantly increased the G.o.T. concentration, while its addition to the TGM diets significantly reduced the concentration. No other interactions of this type were observed for any of the remaining blood serum determinations.

\section{Blood haemoglobin levels}

The mean haemoglobin values in Expts I, 2 and 3 all lay within the range 8-r $2 \mathrm{~g}$ / $100 \mathrm{ml}$ blood, which is considered as normal for pigs of these ages; there was no evidence of any consistent difference in the haemoglobin levels between pigs on the four treatments at any stage of the experiments.

\section{Haematological study in Expt 3 (Table ro)}

The detailed haematological study made after 7 weeks of the experiment showed values all falling within the normal ranges, with the single exception of some of the values for pig 3 on treatment $I$; these would appear to be of doubtful significance in the light of subsequent performance. 
$\frac{0}{\frac{\pi}{0}}$

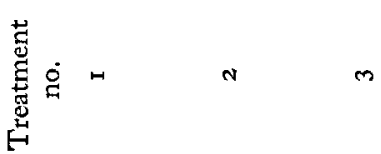




\section{Liver vitamin A concentration (Tables 6 and 8)}

In Expt I (Table 6) neither type of groundnut meal nor $\mathrm{Cu}$ supplementation had any significant effect on the concentration of vitamin $A$ in the liver at slaughter. In Expt 2, however, the presence of TGM had the over-all effect of significantly reducing the liver vitamin A concentration, although $\mathrm{Cu}$ supplementation was again without significant effect. For the reasons mentioned on p. 539 no vitamin A values were determined for the livers from pigs in Expt 3.

\section{Liver and kidney copper concentration (Tables 6, 8 and 9)}

Liver. Type of groundnut meal had no significant effect on liver $\mathrm{Cu}$ concentration in Expts $\mathrm{I}$ and 3, but in Expt 2 (Table 8) there was a significant interaction between type of groundnut meal and Cu supplementation, so that presence of TGM in the diet significantly reduced the liver $\mathrm{Cu}$ concentration in the absence of dietary $\mathrm{Cu}$ supplementation. $\mathrm{Cu}$ supplementation of the diets significantly increased the liver $\mathrm{Cu}$ concentrations in all three experiments and was independent of the type of groundnut meal present in the diet.

Kidney. $\mathrm{Cu}$ concentrations in the kidney were increased when TGM was included in the diet in all three experiments, although the over-all differences were significant in Expts $\mathrm{I}$ and 3 only. Cu supplementation of the diets significantly increased the $\mathrm{Cu}$ values in the kidney independent of the type of groundnut meal present in the diet.

\section{Liver and kidney weights (Expt 3) (Table 9)}

The presence of TGM in the diet significantly increased liver weight by over $65 \%$ on average, irrespective of $\mathrm{Cu}$ supplementation of the diets, but had no effect on kidney weight. Cu supplementation had no significant effect on either liver or kidney weight.

\section{Liver and kidney histological examination (Table I I)}

Extensive damage to both liver and kidneys was caused by the presence of TGM in the diets, and the severity of the damage increased as the level of TGM was increased from $75 \%$ in Expt $\mathrm{I}$ to $\mathrm{I}_{5} \%$ in Expt 3 . There were no lesions suggestive of $\mathrm{Cu}$ toxicity per se. There was no obvious evidence that the presence of $\mathrm{Cu}$ with the TGM influenced the pathological abnormality caused by the latter in either the liver or the kidney.

\section{DISCUSSION}

\section{Daily weight gain and feed conversion efficiency}

The results obtained in the present work on the effects of TGM on the performance of pigs show many features which are in general agreement with observations made by other workers in this field: $(a)$ a reduced susceptibility to aflatoxin $\mathrm{B}_{1}$ poisoning with age of pig; (b) symptoms of inappetance and reduced growth rate but general absence of any marked clinical signs except possibly some unthriftiness (the signs, sometimes reported, of generalized jaundice appear to occur, if at all, only when a pig is on the point of death (Harding et al. 1963)); (c) a low mortality in pigs of over 
2-3 months of age (unless either the level of TGM included in the diet is very high, for example over $27 \%$ in the work reported by Raynaud (1963), or an exceptionally toxic sample of groundnut meal is fed (Carnaghan \& Allcroft, I962; Hornby et al. I962)); (d) a general positive relation between the extent of the adverse effect on the rate of growth exhibited and the level of aflatoxin $B_{1}$ included in the diet fed, were all indicated by the results reported here and have received mention in a majority of published papers and reviews on groundnut poisoning in pigs (Allcroft \& Loosmore, r963; Harding et al. 1963; Allcroft \& Carnaghan, 1963; Annau, Corner, Magwood \& Jericho, 1964; Commercial Research Group, 1964; Bihaly, Kostyak \& Orosny, 1965; Bodnar, Dorman, Juhasz \& Szegedi, I965; Duthie, Lancaster, Taylor, Thomas, Shacklady, Attfield \& Fuller-Lewis, r966; Hintz, Booth, Cucullu, Gardner \& Heitman, I967).

One aspect of the results shown in Tables $2-5$ which should be commented upon is the relation between the effect of the TGM on reducing rate of growth and the associated effects on feed conversion efficiency and total feed consumption, the latter being of particular interest, since, in all the papers already quoted with the single exception of that by Annau et al. ( 1964 ), quantitative details of feed consumption are not given.

In our experiments the adverse effects on daily weight gain of TGM were not primarily the result of an effect on the efficiency with which the feed consumed was utilized, but arose mainly from the reduced intake by the pigs of the aflatoxin $B_{1}$ containing diets (see Table 2 ). This result is contrary to that observed by several other authors, who reported marked worsening of feed conversion efficiency (Annau et al. 1964; Commercial Research Group, 1964; Bihaly et al. 1965; Bodnar, et al. 1965; Duthie et al. 1966). Results more in agreement with those at Shinfield were obtained by Hintz et al. ( 1967 ), using pigs I 2-1 4 weeks of age and on experiment for I $5^{-1} 7$ weeks. These workers found that a dietary level of $0.45 \mathrm{ppm}$, or less, aflatoxin $\mathrm{B}_{1}$ had no significant effect on either daily weight gain or feed conversion efficiency. A level of 0.6 I $5 \mathrm{ppm}$ aflatoxin $B_{1}$ significantly reduced daily weight gain but had no effect on feed conversion efficiency, whereas $0.8 \mathrm{I}$ ppm aflatoxin $B_{1}$ very markedly reduced daily weight gain but had only a small adverse effect on feed conversion efficiency; no results for feed

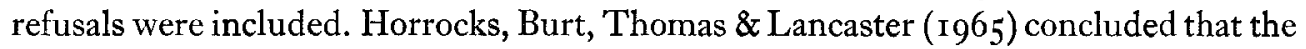
depression in the rate of growth of calves given diets containing up to $0.48 \mathrm{ppm}$ aflatoxin $\mathrm{B}_{1}$ was due to both a lowered feed intake and an impaired feed conversion efficiency.

It is difficult to offer any explanation for these apparently conflicting results concerning the effect of aflatoxin $\mathrm{B}_{\mathbf{1}}$-containing groundnut meal on feed conversion efficiency. It is, of course, recognized that some degree of error must be attached to the daily estimations of feed refusal (as summarized in Table 2), particularly on the occasions when the amounts refused were large. However, in the light of the long experience of those responsible for making these estimates, it is felt that it can be reasonably assumed that, over-all, these errors were unlikely to be of sufficient magnitude to significantly affect the feed conversion efficiency values presented.

One interesting observation we made which might be expected to have some effect on feed conversion efficiency was the tendency for some of the pigs receiving the TGM 
diets to refuse feed in cycles. After a period of heavy feed refusals, lasting several days or even weeks, they would enter a phase of eating well, to be followed in due course by another period of large refusals of feed. This observation fits in with the evidence suggesting that the toxic effects of aflatoxin $\mathrm{B}_{1}$ are not necessarily permanent and that, if it is withdrawn from the diet, a very rapid improvement in the pigs can result with regression of liver lesions (Commercial Research Group, 1964). Presumably the period of heavy feed refusals and consequently much reduced daily intake of aflatoxin $B_{1}$ resulted in some degree of recovery from the toxic effects. The same group of workers also showed that aflatoxin $B_{1}$-containing groundnut meal is less palatable per se to pigs than the non-toxic material, a diet containing the latter being chosen in preference to a TGM diet when the animals were given free choice.

The results obtained in the three experiments show clearly that there was no adverse interaction between TGM and $\mathrm{Cu}$, even when the level of the former was as high as $15 \%$ with an aflatoxin $B_{1}$ content in the diets of $0.90-1.13 \mathrm{ppm}$. On the contrary, the addition of $25^{\circ} \mathrm{ppm} \mathrm{Cu}$ to the TGM diets frequently gave rise to a significant improvement in both daily weight gain and feed conversion efficiency; there was, moreover, a tendency in some instances for such responses to $\mathrm{Cu}$ to be somewhat greater than those obtained on the NTGM diets.

This absence of any adverse interaction between TGM and $\mathrm{Cu}$ affecting the performance of the pigs was in line with the biochemical and histological findings discussed below. With the sole exception of the blood serum G.O.T. level at I4 weeks in Expt 2, there were no significant differences in any of the blood serum determinations or in liver vitamin A stores between the pigs given the TGM diets with or without the $\mathrm{Cu}$ supplement. Similarly, in Expt 3 neither liver nor kidney weight was significantly affected by the addition of $\mathrm{Cu}$ to the TGM diet. The absence of any difference in blood haemoglobin levels between treatments is of particular interest in the light of the reports of lowered haemoglobin levels when toxicity occurred on diets containing $25^{\circ} \mathrm{ppm} \mathrm{Cu}$ (Wallace et al. I960; Ritchie et al. 1963). The histological examination of the livers and kidneys produced no obvious evidence that the presence of the $\mathrm{Cu}$ supplementation in the TGM diet influenced the degree of pathological abnormality caused by TGM.

Thus the results do not support the hypothesis that the isolated instances in which $\mathrm{Cu}$ toxicity has been reported when $25^{\circ} \mathrm{ppm} \mathrm{Cu}$ were added to the diet might have been due to the fact that unknowingly the workers concerned had used aflatoxincontaining feeding-stuffs.

\section{Biochemical results}

The only consistent effect of TGM on the various blood serum determinations was the significantly increased alkaline phosphatase activity observed in all experiments. Comparison of treatments $I$ and 3 also shows that the mean G.o.T. level was higher on the TGM diet on all occasions on which it was measured in Expts I and 2, although the difference was significant only in Expt 2 after I 4 weeks on experiment (Table 7). Harding et al. ( $\mathrm{Ig}_{3}$ ) concluded that the rise in these two liver function tests, which was exhibited by most, but not all, of their experimental pigs, reflected to some extent the histological changes observed in the livers of these animals. An in- 
crease in serum enzyme activity was also reported by Bodnar et al. (1965) when diets containing the very high level of $2.4 \mathrm{ppm}$ aflatoxin $B_{1}$ were fed, although not when a level of up to $0.8 \mathrm{ppm}$ aflatoxin $B_{1}$ was given. It has also been shown that an increase in the serum alkaline phosphatase level occurs in calves fed TGM, which is followed by a fall to normal levels during the few weeks preceding death (Allcroft \& Lewis, 1963).

Annau et al. (1964) carried out a detailed study of the serum protein pattern of pigs given various amounts of aflatoxin $B_{1}$-containing groundnut meal. Their results indicated that with a level of $0.75 \mathrm{ppm}$ aflatoxin $B_{1}$ in the diet for 70 days or more there was a tendency for total serum protein to be reduced and for there to be marked reductions in albumin and $\alpha$ - and $\beta$-globulins and a very considerable increase in $\gamma$-globulin. By contrast, comparison of treatments I and 3 shows that the TGM used in our studies had no consistent significant effect on either total protein, albumin or the albumin:globulin ratio at any level of inclusion. No explanation is apparent for these differing results.

The significant decrease in liver vitamin A concentrations in Expt 2 when $15 \%$ TGM was fed from 9 weeks to slaughter (although not in Expt I when only $7.5 \%$ TGM was included) is in agreement with the results of Harding et al. (1963) in pigs and of those described in calves by Allcroft \& Lewis (1963). These results indicate that the ability of the damaged liver to store vitamin $\mathrm{A}$ is greatly reduced.

$\mathrm{Cu}$ concentrations in the livers and kidneys both exhibited the well-documented substantial increases when the diets supplemented with $25^{\circ} \mathrm{ppm} \mathrm{Cu}$ were given. The mean liver $\mathrm{Cu}$ concentrations of both control and $\mathrm{Cu}$-fed pigs showed considerable variation from one experiment to another, the levels declining as the amount of groundnut meal in the diets (both NTGM and TGM) increased. However, all the mean concentrations fall within the wide range of reported values (see Braude, 1965) and no conclusions on the significance of the above decline are possible. Kidney $\mathrm{Cu}$ concentrations were also within the expected ranges for control and Cu-supplemented pigs, respectively, in Expts I and 2, with the exception of the somewhat elevated value for treatment 4 in both experiments. In Expt 3, however, the mean kidney values for the $\mathrm{Cu}$-supplemented pigs, whether given NTGM or TGM, were considerably higher than is normally to be expected. Again, the significance of this latter observation is not clear. It is, however, of interest to note that, though type of groundnut meal had no consistent significant effect over-all on liver $\mathrm{Cu}$ concentration, kidney $\mathrm{Cu}$ levels were increased in all three experiments when TGM was included in the diet, the difference on average increasing as the level of TGM in the diet increased.

The very striking increase in total liver weight, which was determined only in Expt 3, when ${ }_{5} \%$ TGM was fed throughout, does not appear to have been so clearly demonstrated previously, although some evidence for such an increase can be seen in the results given by Harding et al. ( 1963$)$. Dry-matter percentages for livers in Expt 3 were not available (see p. 539), but as there was no indication from the results available for the livers of pigs in Expts I and 2 that TGM reduced the dry-matter percentage, it may reasonably be concluded that, though TGM had no significant effect on liver $\mathrm{Cu}$ concentration, it did increase the total $\mathrm{Cu}$ stores in the liver as a result of its effect on total liver weight. 


\section{Histological observations}

The liver lesions, summarized in Table $\mathbf{I}$, were qualitatively similar to those already described in groundnut poisoning in pigs (Loosmore \& Harding, 196r; Harding et al. 1963; Allcroft \& Loosmore, 1963; Commercial Research Group, 1964; Annau et al. I964; Bodnar et al. 1965; Duthie et al. 1966; Hintz et al. 1967), though the degree of renal karyomegaly was often greater than previously seen in groundnut poisoning and sometimes came near to the renal lesions seen in Senecio jacobaea poisoning in pigs (Harding, Lewis, Done \& Allcroft, 1964). A few pigs developed hepatic karyomegaly without the other typical lesions of groundnut poisoning, thus differing from the sequence of development of lesions in previous experiments, in which ductule proliferation and fibrosis preceded karyomegaly (Harding et al. 1963). The extent of the liver and kidney lesions in treatments 3 and 4 were in general very similar and it would appear that the dietary supplement of $250 \mathrm{ppm} \mathrm{Cu}$ did not significantly influence the degree of pathological abnormality caused by the TGM. Though the correlation between stainable and analysed $\mathrm{Cu}$ in livers was not very close, it seems that the rubeanic acid method used would detect $\mathrm{Cu}$ at a level of about $120 \mathrm{ppm}$ and above.

\section{REFERENCES}

Allcroft, R. \& Carnaghan, R. B. A. (1963). Chemy Ind. p. 50.

Allcroft, R. \& Lewis, G. (1963). Vet. Rec. 75, 487 .

Allcroft, R. \& Loosmore, R. M. (1963). Proc. int. vet. Congr. xvil. Hanover 1, 175 .

Allen, M. M. \& Harding, J. D. J. (1962). Vet. Rec. 74, 173.

Annau, E., Corner, A. H., Magwood, S. E. \& Jericho, K. (r964). Can. F. comp. Med. 28, 264.

Barber, R. S., Braude, R. \& Mitchell, K. G. (I955). Vet. Rec. 67, 348.

Barber, R. S., Braude, R., Mitchell, K. G. \& Cassidy, J. (1955). Chemy Ind. p. 601.

Bass, B., McCall, J. T., Wallace, H. D., Combs, G. E., Palmer, A. Z. \& Carpenter, J. E. (1956). F. Anim. Sci. 15, 1230.

Bihaly, A., Kostyak, J. \& Orosny, D. (1965). Allattenyesztes 14, 243.

Bodnar, M., Dorman, M., Juhasz, B. \& Szegedi, B. (1965). Magy Allatorv. Lap. 20, 390.

Braude, R. (1965). Transactions of a Symposium on Cuprum pro Vita, Vienna, p. 55. Also published in Wld Rev. Anim. Prod. (1967) 3, 69 .

Braude, R. \& Mitchell, K. G. (I95I). F. Minist. Agric. Fish. 57, 50 I.

Buntain, D. (I96I). Vet. Rec. 73, 707.

Carnaghan, R. B. A. \& Allcroft, R. (I962). Vet. Rec. 74, 925.

Carr, F. H. \& Price, E. A. (1926). Biochem. F. 20, 497.

Clare, N. T., Cunningham, I. J. \& Perrin, D. D. (1945). N.Z. Fl Sci. Technol. 26 A, 340.

Commercial Research Group (1964). Vet. Rec. 76, 498.

de Iongh, H., van Pelt, J. G., Ord, W. O. \& Barrett, C. B. (1964). Vet. Rec. 76, gor.

Duncan, D. B. (1955). Biometrics II, I.

Duthie, I. F., Lancaster, M. C., Taylor, J., Thomas, D. C., Shacklady, C. A., Attfield, P. H. \& FullerLewis, E. (1966). Vet. Rec. 79, 621 .

Eden, A. \& Green, H. H. (1940). Biochem. F. 34, 1202.

Gordon, W. A. M. \& Luke, D. (1957). Vet. Rec. 69, 37.

Hanrahan, T. J. \& O'Grady, J. F. (I966), Anim. Prod. 8, 36 I.

Harding, J. D. J., Done, J. 'T., Lewis, G. \& Allcroft, R. (I963). Res. vet. Sci. 4, 2 I 7.

Harding, J. D. J., Lewis, G., Done, J. T. \& Allcroft, R. (1964). Path. Vet. 1, 204.

Hintz, H. F., Booth, A. N., Cucullu, A. F., Gardner, H. K. \& Heitman, H., Jr (I967). Proc. Soc. exp. Biol. Med. 124, 266.

Hornby, R. B., Miller, J. C. \& Dabell, J. S. ( I962). Vet. Rec. 74, 52.

Horrocks, D., Burt, A. W. A., Thomas, D. C. \& Lancaster, M. C. (r965). Anim. Prod. 7, 253.

King. E. J. \& Wootton, I. D. P. (1956). Micro-analysis in Medical Biochemistry, 3rd ed. London: Churchill.

Loosmore, R. M., Allcroft, R., Tutton, E. A. \& Carnaghan, R. B. A. (1964). Vet. Rec. 76, 64. 
Loosmore, R. M. \& Harding, J. D. J. (1961). Vet. Rec. 73, 1362.

Lysø, A. ( 1966$)$. Meld. Norg. LandbrHøgsk. no. 45.

O'Hara, P. J., Newman, A. P. \& Jackson, R. (1960). Aust. vet. Y. 36, 225.

Okamoto, K. \& Utamura, N. (1937). Scholae med. Kioto acta 320, 573.

Raynaud, J. P. (1963). Rev. Elev. Med. vet. Pays trop. 16, 23.

Ritchie, H. D., Luecke, R. W., Baltzer, B. V. Miller, E. R., Ullrey, D. E. \& Hoefer, J. A. (rg63). F. Nutr. 79, 17.

Thompson, S. Y., Ganguly, J. \& Kon, S. K. (1949). Br. F. Nutr. 3, 50.

Umbreit, W. W., Kingsley, G. R., Schaffert, R. R. \& Siplet, H. (r957). F. Lab. clin. Med. 49, 454.

Van der Merwe, K. F., Fourie, L. \& Scott de B. (1963). Chemy Ind. p. I660.

Wallace, H. D., McCall, J. T., Bass, B. \& Combs, G. E. (1960). F. Anim. Sci. I9, xr53.

Wroblewski, F. \& Caband, P. (1957). Am. J. clin. Path. 27, 235. 